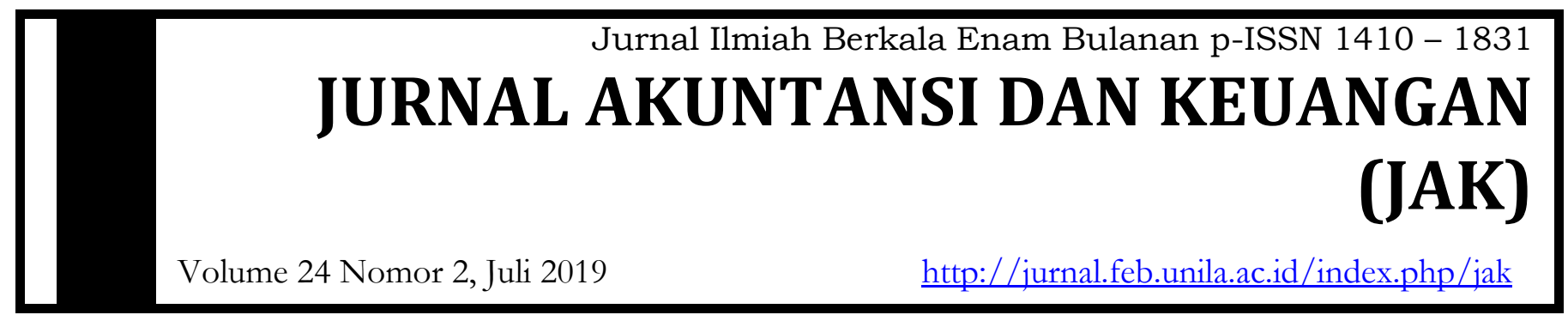

\title{
PENGARUH PERTUMBUHAN EKONOMI, PAD, DAU TERHADAP PENGALOKASIAN ANGGARAN BELANJA MODAL PADA KABUPATEN/KOTA SUMATERA SELATAN
}

\author{
Putri Retno Aryani1 ${ }^{1}$ Kurnia Krisna Hari ${ }^{2}$ \\ ${ }^{1}$ Universitas Muhammadiyah Palembang \\ ${ }^{2}$ Universitas Muhammadiyah Palembang
}

\section{Informasi Naskah}

Update Naskah:

Dikumpulkan: 28 Mei 2019

Diterima: 22 Juni 2019

Terbit/Dicetak: 30 Juni 2019

\section{Keywords:}

Economic Growth, PAD, DAU and Capital Expenditure

\begin{abstract}
This research is aimed at determining the influence ofeconomic growth, local revenue and general fund allocation toward appropriation of capital budget In Districts/City in South Sumatera Province. The samples used in this study were 11 districts/cities in South Sumatera Province in line with the source of Realization Report Budget (APBD) which was accessed from www.djpk.depkeu.go.id and Economic Growth which was obtained from the Central Statistics Agency of South Sumatera Province. The data used in this research was secondary data. The technique of analyzing the data was using multiple regression test.

Simulataneously, the results showed that Economic Growth, Local Revenue and General Fund Allocation had positive significant influence toward capital expenditures. While, partially, the results showed that Economic Growth had no positive significant influence toward toward Capital Expenditure, regional revenue had no positive significant influence toward Capital Expenditure, General Fund Allocation had positive significant toward Capital Expenditure.
\end{abstract}




\section{A. PENDAHULUAN}

Undang-Undang Nomor 32 Tahun 2004 tentang Pemerintahan Daerah memberikan kewenangan penuh bagi tiap-tiap daerah baik provinsi, kabupaten/kota untuk mengatur dan mengurus rumah tangga daerahnya dengan sedikit mungkin campur tangan pemerintah pusat. Kebijakan tersebut dikenal dengan Otonomi Daerah. Otonomi daerah bertujuan untuk mempercepat pertumbuhan ekonomi dan pembangunan daerah, meningkatkan kuantitas pelayanan publik agar lebih efisien dan responsif terhadap kebutuhan potensi maupun karakteristik di daerah masing-masing serta mengurangi ketidakmerataan pembangunan yang berjalan selama ini sehingga menyebabkan ketimpangan antar pemerintah pusat dan daerah.

Pertumbuhan ekonomi daerah merupakan salah satu indikator keberhasilan pencapaian pembangunan daerah. Gambaran kebijakan pembangunan di suatu daerah dengan memperhatikan pertumbuhan ekonomi, telah berorientasi terhadap pertumbuhan ekonomi yang berkelanjutan sebagai salah satu kunci untuk menetapkan perekonomian daerah demi peningkatan kesejahteraan rakyat.

Untuk mendorong pertumbuhan ekonomi, diharapkan desentralisasi fiskal dapat memberikan dampak yang positif dan signifikan terhadap pertumbuhan ekonomi. Dalam era desentralisasi fiskal diharapkan terjadinya peningkatan pelayanan di berbagai sektor terutama sektor publik. Peningkatan layanan publik ini diharapkan dapat meningkatkan daya tarik investor untuk membuka usaha di daerah. Harapan ini tentu saja dapat terwujud apabila ada upaya pemerintah dengan memberikan berbagai fasilitas untuk investasi. Konsekuensinya pemerintah perlu memberikan alokasi belanja yang lebih besar untuk tujuan ini. Salah satu belanja yang dilakukan oleh pemerintah daerah adalah belanja modal. Menurut Halim (2014: 107), Belanja modal merupakan pengeluaran anggaran untuk perolehan aset tetap dan aset lainnya yang memberikan manfaat lebih dari satu periode akuntansi. Anggaran ini sebenarnya dimaksudkan untuk memenuhi kebutuhan publik akan sarana dan prasarana umum yang disediakan oleh pemerintah daerah.

Diterapkannya otonomi daerah baik di provinsi, kabupaten/kota memberikan keleluasaan kepada pemerintah daerah setempat untuk menggali potensi-potensi sumber keuangan di daerahnya sekaligus dapat mengalokasikan sumber daya ke belanja daerah sesuai kebutuhan dan aspirasi masyarakat di daerahnya. Semakin banyak sumber-sumber keuangan yang berhasil digali di suatu daerah, maka hal ini akan meningkatkan pendapatan daerah yang semestinya diikuti dengan meningkatnya pertumbuhan ekonomi di daerah tersebut. Pertumbuhan ekonomi yang tinggi mendorong pemerintah daerah untuk melakukan pembangunan daerah yang direalisasikan dalam pengadaan fasilitas, infrastruktur dan sarana prasarana yang ditujukan untuk kepentingan publik. Pertumbuhan ekonomi di daerah diproksikan dengan menggunakan Produk Domestik Regional Bruto. Pertumbuhan ekonomi semestinya mampu mendorong pembangunan daerah yang nantinya dapat meningkatkan alokasi belanja modal daerah.

Berdasarkan Undang-Undang Nomor 33 Tahun 2004, sumber-sumber pendanaan daerah salah satunya berasal dari Pendapatan Asli Daerah yang selanjutnya disebut PAD. Menurut Halim (2014 : $102-$ 104), Pendapatan Asli Daerah merupakan penerimaan yang diperoleh Pemerintah Daerah dari sumbersumber dalam wilayahnya sendiri yang dipungut berdasarkan Peraturan Daerah (Perda) yang terdiri atas pajak daerah, retribusi daerah, hasil pengelolaan kekayaan daerah, dan lain-lain dari PAD yang sah. Tujuan PAD sendiri adalah untuk memberikan kewenangan kepada Pemerintah Daerah untuk mendanai pelaksanaan otonomi daerah sesuai dengan potensi daerah sebagai perwujudan desentralisasi.

Peningkatan PAD diharapkan mampu mendorong meningkatkan investasi belanja modal pemerintah daerah sehingga kulaitas pelayanan publik semakin baik.

Kemampuan setiap daerah tidak sama dalam mendanai berbagai kegiatan, hal ini menimbulkan adanya kesenjangan fiskal antar satu daerah dengan daerah lainnya. Untuk mengatasi hal tersebut, Pemerintah mengalokasikan dana transfer yang bersumber dari Anggaran Pendapatan dan Belanja Negara (APBN) untuk mendanai kebutuhan daerah dalam pelaksanaan desentralisasi. Menurut Amandemen Undang-Undang Pemerintah Daerah (UU Republik Indonesia Nomor 23 Tahun 2014) tentang Pemerintahan Daerah (Pemda) bahwa dana perimbangan meliputi Dana Bagi Hasil, Dana Alokasi Umum (DAU), dan Dana Alokasi Khusus (DAK). Dana Alokasi Umum (DAU) salah satu dana perimbangan dari 
pemerintah yang pengalokasiannya menekankan aspek pemerataan dan keadilan yang selaras dengan penyelenggaraan urusan pemerintah. DAU merupakan penyangga utama pembiayaan Anggaran Pendapatan dan Belanja Daerah (APBD) yang sebagian besar terserap untuk belanja pegawai, sehingga belanja untuk proyek-proyek pembangunan sangat berkurang. Adanya dana transfer dari Pemerintah Pusat diharapkan Pemda bisa lebih mampu mengalokasikan Pendapatan Asli Daerah (PAD) yang didapat untuk membiayai belanja modal.

Pemerintah Kabupaten/Kota Provinsi Sumatera Selatan yang terdiri dari 17 Kabupaten/Kota dalam beberapa tahun berjalan proporsi DAU terhadap daerah masih sangat tinggi dibandingkan dengan penerimaan daerah yang lain termasuk Pendapatan Asli Daerah (PAD). Hal ini menunjukkan masih tingginya ketergantungan Pemda terhadap pasokan dari Pemerintah Pusat sehingga menyebabkan tidak stabilnya kontribusi PAD terhadap Anggaran.

Menurut penelitian yang dilakukan Mayasari, dkk (2014) yang menyatakan bahwa pertumbuhan ekonomi, PAD dan DAU berpengaruh signifikan terhadap Belanja Modal. Berbeda dengan penelitian yang dilakukan oleh Maslikah (2014) menyatakan bahwa pertumbuhan ekonomi tidak berpengaruh terhadap anggaran belanja modal dan penelitian yang dilakukan oleh Widianto (2013) menyatakan bahwa PAD berpengaruh negatif terhadap belanja modal serta penelitian yang dilakukan Sumarmi (2008) menyatakan bahwa hasil penelitian menunjukkan secara parsial bahwa DAU berpengaruh negatif terhadap alokasi belanja modal APBD.

\section{Kerangka Hipotesis}

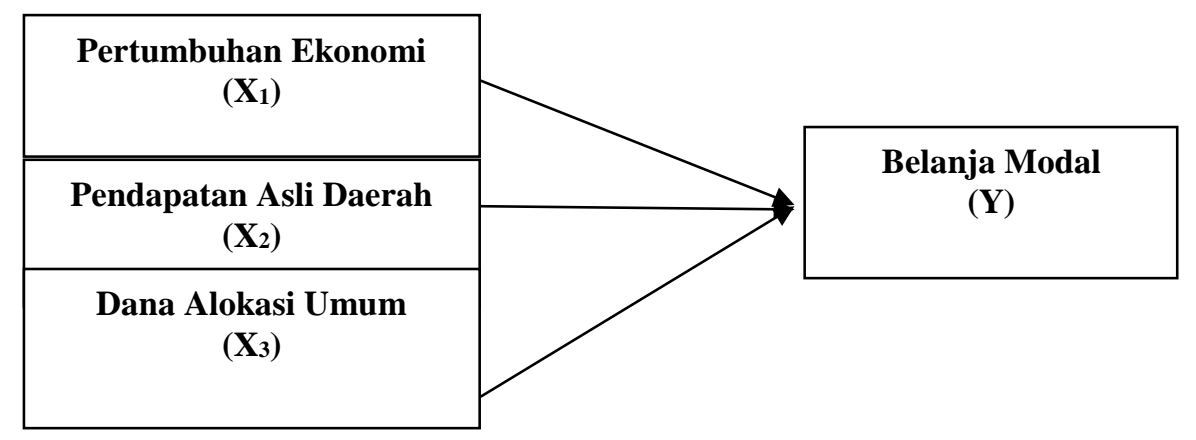

Kerangka Pemikiran Teoritis Pengaruh Pertumbuhan Ekonomi, PAD dan DAU terhadap Belanja Modal

\section{Hipotesis Penelitian}

Adapun hipotesis dalam penelitian ini adalah:

1. Pengaruh Pertumbuhan Ekonomi, Pendapatan Asli Daerah dan Dana Alokasi Umum terhadap Pengalokasian Anggaran Belanja Modal secara Simultan.

Pertumbuhan ekonomi bertujuan untuk peningkatan ekonomi yang berkelanjutan. Kebijakan otonomi daerah mendorong terciptanya pertumbuhan ekonomi suatu daerah. Pertumbuhan ekonomi masingmasing daerah berbeda-beda sesuai dengan potensi tiap-tiap daerah. Sehingga semakin tinggi tingkat pertumbuhan suatu daerah tentu akan mengakibatkan bertumbuhnya ekonomi investasi modal swasta maupun pemerintah. Pemerintah daerah dalam membiayai belanja daerahnya menggunakan sumber dananya sendiri yaitu Pendapatan Asli Daerah. Pada Pemerintahan daerah di Indonesia, Pendapatan cenderung mempengaruhi Belanja. Hal ini dapat dilihat dari kebiasaan di daerah yang menunggu kepastian DAU dulu baru menentukan alokasi belanja dalam APBD. Mayasari, dkk (2014) menyatakan bahwa yang mengatakan pertumbuhan ekonomi, Pendapatan Asli Daerah dan Dana Alokasi Umum berpengaruh signifikan terhadap Belanja Modal. Berdasarkan landasan teoritis dan temuan-temuan empiris di atas, hipotesis dapat dinyatakan sebagai berikut:

$\mathrm{H}_{1}$ = Pertumbuhan Ekonomi, Pendapatan Asli Daerah dan Dana Alokasi Umum berpengaruh positif terhadap Pengalokasian Anggaran Belanja Modal. 
2. Pengaruh Pertumbuhan Ekonomi terhadap Pengalokasian Anggaran Belanja Modal secara Parsial. Pertumbuhan ekonomi ialah proses output per kapita yang terus menerus dalam jangka panjang. Pertumbuhan ekonomi tersebut merupakan salah satu indikator keberhasilan pembangunan. Sehingga makin tingginya pertumbuhan ekonomi maka makin tinggi pula kesejahteraan masyarakatnya, meskipun terdapat indikator lain yaitu distribusi pendapatan. Hasil penelitian yang dilakukan oleh Mayasari, dkk (2014) terdapat pengaruh yang signifikan dari pertumbuhan ekonomi terhadap belanja modal. Dari landasan teori dan temuan empiris-empiris di atas menghasilkan hipotesis berikut:

\section{$\mathbf{H}_{2}=$ Pertumbuhan Ekonomi berpengaruh positif terhadap Pengalokasian Anggaran Belanja}

\section{Modal}

3. Pengaruh Pendapatan Asli Daerah terhadap Pengalokasian Anggaran Belanja Modal secara Parsial. Desentralisasi fiskal memberikan kewenangan kepada daerah untuk mengurus dan mengatur semua urusan pemerintahan dengan membuat kebijakan daerah untuk memberi pelayanan, peningkatan peran serta prakarsa dan pemberdayaan masyarakat setempat yang bertujuan untuk peningkatan kesejahteraan masyarakat (Undang-Undang Nomor 32 Tahun 2004). Kemampuan daerah untuk menyediakan sumber-sumber pendapatan yang berasal dari daerah sangat tergantung pada kemampuan merealisasikan potensi ekonomi daerah setempat menjadi bentuk-bentuk kegiatan ekonomi yang mampu menciptakan penerimaan daerah untuk membiayai pembangunan daerah tersebut. Wertianti dan Dwirandra (2013) menyatakan bahwa PAD berpengaruh positif dan signifikan terhadap terhadap alokasi belanja modal. Temuan ini dapat mengindikasikan bahwa besarnya PAD menjadi salah satu faktor penentu dalam menentukan belanja modal. Berdasarkan landasan teoritis dan temuan-temuan empiris di atas, hipotesis dapat dinyatakan sebagai berikut:

H3 $_{3}$ Pendapatan Asli Daerah berpengaruh positif terhadap Pengalokasian Anggaran Belanja Modal

4. Pengaruh Dana Alokasi Umum terhadap Pengalokasian Anggaran Belanja Modal secara Parsial. Pada pelaksanaan desentralisasi, pemerintah pusat menyerahkan kewenangannya kepada pemerintah daerah, menimbulkan konsekuensi pemberian sumber keuangan negara kepada pemerintah daerah dengan memperhatikan stabilitas dan keseimbangan fiskal. Dana perimbangan ini bertujuan untuk mengurangi kesenjangan fiskal antara pemerintah daerah pusat dan pemerintah daerah antar pemerintah daerah itu sendiri. Salah satu dana perimbangan adalah DAU yaitu dana yang berasal dari APBN yang dialokasikan dengan tujuan pemerataan keuangan antar daerah untuk membiayai kebutuhan pengeluarannya dalam rangka pelaksanaan desentralisasi. Dengan demikian, terjadi transfer yang cukup signifikan dari pemerintah pusat ke pemerintah daerah, dan pemerintah daerah dapat menggunakan dana ini untuk melaksanakan fungsi layanan dasar umum. Berdasarkan penelitian empiris yang dilakukan oleh Maslikah (2014) menyatakan Dana Alokasi Umum berpengaruh signifikan terhadap anggaran belanja modal. Landasan teoritis dan temuan-temuan empiris di atas menghasilkan hipotesis sebagai berikut:

\section{$\mathrm{H}_{4}$ = Dana Alokasi Umum berpengaruh positif terhadap Pengalokasian Anggaran Belanja Modal}

\section{B. LANDASAN TEORI DAN PENGEMBANGAN HIPOTESIS}

Menurut Sukirno (2015: 423), dalam kegiatan perekonomian yang sebenarnya pertumbuhan ekonomi berarti perkembangan fisikal produksi barang dan jasa yang berlaku di suatu negara, seperti pertambahan dan jumlah produksi barang industri, perkembangan infrastruktur, pertambahan jumlah sekolah, pertambahan produksi sektor jasa dan pertambahan produksi barang modal.

Pertumbuhan ekonomi suatu daerah dicerminkan dari angka Produk Domestik Regional Bruto (PDRB) yang merupakan nilai tambah bruto seluruh barang dan jasa yang tercipta atau dihasilkan di wilayah domestik suatu negara yang timbul akibat berbagai aktivitas ekonomi dalam suatu periode tertentu tanpa memperhatikan apakah faktor produksi yang dimiliki residen atau non-residen. Perhitungan PDRB 
menggunakan dua macam harga yaitu PDRB atas harga berlaku merupakan nilai tambah barang dan jasa yang dihitung menggunakan harga yang berlaku pada tahun bersangkutan, sementara PDRB atas dasar konstan dihitung dengan menggunakan harga pada tahun tertentu sebagai tahun dasar (Badan Pusat Statistik, 2015).

Menurut Siregar (2015: 31), Pendapatan Asli Daerah adalah penerimaan yang diperoleh Pemda dari sumber-sumber dalam wilayahnya sendiri yang dipungut berdasarkan Peraturan Daerah. Pendapatan Asli Daerah meliputi pajak daerah, retribusi daerah, hasil pengelolaan kekayaan daerah yang dipisahkan, dan lain-lain PAD yang sah. Dana Alokasi Umum merupakan dana yang ditujukan untuk memeratakan kemampuan keuangan daerah secara horizontal. DAU dialokasikan untuk provinsi dan kabupaten/kota. DAU merupakan dana yang ditujukan untuk memeratakan kemampuan keuangan daerah secara horizontal. Belanja modal merupakan pengeluaran untuk pengadaan aset tetap. Dalam akuntansi berbasis akrual, pengeluaran untuk memperoleh aset tetap dikategorikan sebagai aset tetap. Belanja modal dapat diklasifikasikan sesuai dengan kategori aset tetap adalah sebagai berikut:

a) Belanja Modal Tanah

b) Belanja Modal Peralatan dan Mesin

c) Belanja Modal Gedung dan Bangunan

d) Belanja Modal Jalan, Irigasi, dan Jaringan

e) Belanja Aset Tetap Lainnya

\section{METODE PENELITIAN}

\section{Tempat Penelitian}

Tempat penelitian dilakukan di Kantor Badan Pusat Statistik Provinsi Sumatera Selatan dan diperoleh melalui situs resmi pemerintah www.djpk.depkeu.go.id.

\section{Jenis Penelitian dan Sumber Data}

Jenis penelitian yang akan digunakan adalah penelitian Asosiatif. Data yang digunakan dalam penelitian ini adalah data sekunder. Metode pengumpulan data yang digunakan dalam penelitian ini adalah dokumentasi. Analisis data yang digunakan adalah analisis kualitatif dan kuantitatif.

\section{Teknik Pengumpulan Data dan Teknik Analisis}

Teknik pengumpulan data melalui dokumentasi. Teknik analisis data yang digunakan statistik deskriptif dan uji regresi linier berganda dan dibantu oleh program Statistical Package For The Social Science (SPSS).

\section{ANALISIS DAN PEMBAHASAN}

\section{Statistik Deskriptif}

Berdasarkan hasil uji statistik deskriptif diperoleh gambaran nilai mean serta standar deviasi masingmasing variabel yaitu Pertumbuhan Ekonomi (PDRB), Pendapatan Asli Daerah, Dana Alokasi Umum dan Belanja Modal.

\section{Uji Normalitas}

Berdasarkan hasil Uji Normalitas dapat diketahui bahwa nilai residual untuk data sebesar 0,691 yang berarti > 0,05 signifikansi residualnya berdistribusi normal.

\section{Hasil Uji Asumsi Klasik}

Berdasarkan hasil uji asumsi klasik didapat bahwa nilai DW adalah 1.896 yang berarti nilai tersebut berada di antara -2 sampai +1 jadi dapat disimpulkan bahwa tidak terdapat gejala autokorelasi pada model dalam penelitian ini.

\section{Hasil Uji Multikolinearitas}

Berdasarkan hasil uji multikolinearitas menunjukkan output coefficients nilai VIF masing-masing variabel 
pada kolom output coefficients untuk variabel $\mathrm{X}_{1}$ sebesar 1,004 dan untuk variabel $\mathrm{X}_{2}$ sebesar 2,447 dan variabel $\mathrm{X}_{3}$ sebesar 2,447. Ketiga nilai variabel lebih besar dari 0,10 sehingga dapat disimpulkan bahwa tidak terjadi persoalan multikolonieritas antar variabel bebas dalam penelitian ini.

\section{Hasil Uji Heterokedasitas}

Berdasarkan hasil uji heterokedasitas didapat bahwa dari hasil Uji Glejser dilihat bahwa nilai signifikansi dari seluruh variabel bebas yaitu Pertumbuhan Ekonomi (PDRB), Pendapatan Asli Daerah dan Dana Alokasi Umum berada di atas 0,05 yang berarti model regresi tidak terdapat heterokedasitas.

\section{Analisis Regresi Linier Berganda}

Dari hasil perhitungan analisis linier berganda melalui program SPSS, diperoleh persamaan regresi berganda dapat dituliskan sebagai berikut:

$$
Y=161779,475-5408,093 X_{1}+0,001 X_{2}+0,442 X_{3}+e
$$

Dimana:

1) Konstanta sebesar 161779,475 menyatakan bahwa jika Pertumbuhan Ekonomi (PDRB), PAD dan DAU bernilai nol maka skor belanja modal sebesar 161779,475.

2) Koefisien regresi $X_{1}$ sebesar $-5408,093$ bernilai negatif menyatakan bahwa setiap pengurangan satu satuan skor Pertumbuhan Ekonomi (PDRB) $\left(\mathrm{X}_{1}\right)$ akan mengurangi nilai belanja modal sebesar 5408,093 dengan menjaga variabel lain tetap/konstan.

3) Koefisien regresi $X_{2}$ sebesar 0,001 bernilai positif menyatakan bahwa setiap penambahan satu satuan skor PAD $\left(\mathrm{X}_{2}\right)$ akan meningkatkan skor belanja modal sebesar 0,001 dengan menjaga variabel lain tetap/konstan.

4) Koefisien regresi $X_{3}$ sebesar 0,442 bernilai positif menyatakan bahwa setiap penambahan satu satuan skor DAU $\left(\mathrm{X}_{3}\right)$ akan meningkatkan nilai belanja modal sebesar 0,442 dengan menjaga variabel lain tetap/konstan.

\section{Uji Korelasi dan Determinasi $\left(\mathbf{R}^{2}\right)$}

Berdasarkan hasil perhitungan Uji Korelasi dan Determinasi $\left(\mathrm{R}^{2}\right)$ dengan melalui program SPSS dapat diintepretasikan sebagai berikut:

- Nilai korelasi (R) diperoleh sebesar = 0,608 yang berarti bahwa hubungan atau tingkat asosiasi variabel bebas yaitu PDRB, PAD dan DAU dengan variabel terikat yaitu belanja modal adalah cukup.

- $\quad$ Angka Adjusted $R$ Square (nilai koefisien determinasi $\left(\mathrm{R}^{2}\right)$ sebesar 0,369 memberikan makna bahwa variabel PDRB, PAD dan DAU mampu menjelaskan perubahan terhadap variabel belanja modal sebesar 36,9\%, sedangkan sisanya dijelaskan oleh variabel-variabel lain yang tidak termasuk dalam penelitian ini.

\section{Hasil Uji F dan Uji t}

Hasil Uji F

\begin{tabular}{|l|l|l|r|c|c|c|}
\hline Model & & Sum of Squares & \multicolumn{1}{c|}{ df } & Mean Square & F & Sig. \\
\hline 1 & Regression & 317712245661.036 & 3 & 105904081887.01 & 5.657 & $.004^{\text {b }}$ \\
& Residual & 542936739909.510 & 29 & 18721956548.604 & & \\
& Total & 860648985570.545 & 32 & & & \\
\hline
\end{tabular}

a. Dependent Variable: Belanja Modal

b. Predictors: (Constant), DAU, PDRB, PAD

Sumber : Hasil pengolahan data SPSS 20, 2017

Dapat dilihat bahwa nilai $F_{\text {hitung }}$ diperoleh sebesar 5,657 lebih besar dari $F_{\text {tabel }}(2,934)$, hal ini juga diperkuat dengan nilai taraf signifikansi sebesar 0,004 atau signifikansi yang diperoleh lebih kecil dari $\alpha=$ 0,05, artinya $\mathrm{H}_{0}$ ditolak, $\mathrm{H}_{\mathrm{a}}$ diterima. Maka dapat disimpulkan bahwa Pertumbuhan Ekonomi (PDRB) $\left(\mathrm{X}_{1}\right)$, 
Pendapatan Asli Daerah $\left(\mathrm{X}_{2}\right)$ dan Dana Alokasi Umum $\left(\mathrm{X}_{3}\right)$ berpengaruh positif dan signifikan terhadap belanja modal (Y).

Hasil Uji t

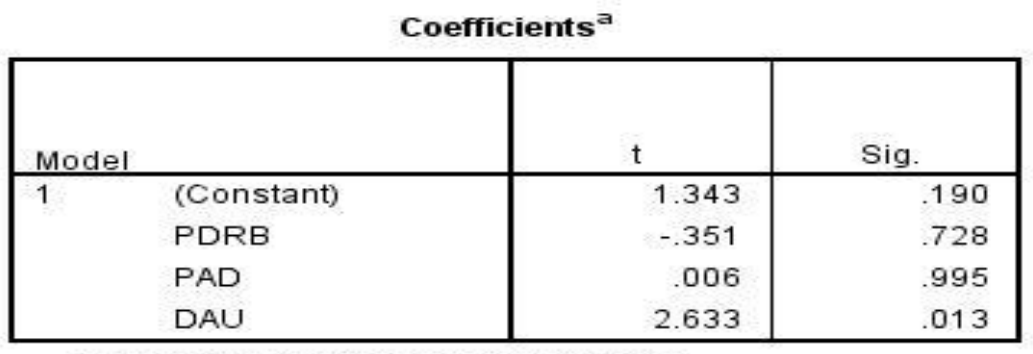

a. Dependent Variable: Belanja Modal

Sumber : Hasil pengolahan data SPSS 20, 2017

Berdasarkan tabel di atas dapat terlihat bahwa output SPSS bahwa:

1) $\mathrm{H}_{0}$ diterima dan $\mathrm{H}_{\mathrm{a}}$ ditolak.

Pertumbuhan Ekonomi (PDRB) ( $\left.\mathrm{X}_{1}\right)$ mempunyai hubungan negatif, hal ini berarti bila PDRB diturunkan, maka belanja modal juga turun. Hal ini dibuktikan dengan nilai thitung untuk variabel $\mathrm{X}_{1}$ sebesar $-0,351$, sedangkan $t_{\text {table }}$ sebesar 2,045 , maka $-t_{\text {hitung }}(-0,351)>t_{\text {tabel }}(-2,045)$. Hal ini juga diperkuat dengan nilai signifikan $0,728(0,728>0,05)$, maka dapat disimpulkan PDRB berpengaruh negatif dan tidak signifikan terhadap belanja modal.

2) $\mathrm{H}_{0}$ ditolak dan $\mathrm{H}_{\mathrm{a}}$ diterima.

PAD $\left(\mathrm{X}_{2}\right)$ mempunyai hubungan positif, hal ini berarti bila PAD ditingkatkan, maka belanja modal juga meningkat. Hal ini dibuktikan dengn nilai $t_{\text {hitung }}$ untuk variabel $\mathrm{X}_{2}$ sebesar 0,006 , sedangkan $\mathrm{t}_{\text {table }}$ sebesar 2,045, maka thitung $(0,006)<\mathrm{t}_{\text {tabel }}(2,045)$. Hal ini juga diperkuat dengan nilai signifikan 0,995 $(0,995>0,05)$, maka dapat disimpulkan PAD berpengaruh positif dan tidak signifikan terhadap belanja modal.

3) $\mathrm{H}_{0}$ ditolak dan $\mathrm{H}_{\mathrm{a}}$ diterima.

DAU $\left(\mathrm{X}_{3}\right)$ mempunyai hubungan positif, hal ini berarti bila DAU ditingkatkan, maka belanja modal juga meningkat. Hal ini dibuktikan dengan nilai thitung untuk variabel $\mathrm{X}_{3}$ sebesar 2,633, sedangkan table sebesar 2,045, maka $t_{\text {hitung }}(2,633)>t_{\text {tabel }}(2,045)$. Hal ini juga diperkuat dengan nilai signifikan 0,013 $(0,013<0,05)$, maka dapat disimpulkan DAU berpengaruh positif dan signifikan terhadap belanja modal.

\section{Pembahasan}

\section{1) Pengaruh Pertumbuhan Ekonomi, Pendapatan Asli Daerah dan Dana Alokasi Umum terhadap Pengalokasian Anggaran Belanja Modal secara Simultan}

Pemberian otonomi daerah berpengaruh terhadap pertumbuhan ekonomi suatu daerah karena memberikan kebebasan kepada pemerintah daerah untuk membuat rencana keuangannya sendiri dan membuat kebijakan-kebijakan yang dapat berpengaruh pada kemajuan daerahnya. Pertumbuhan ekonomi dengan mengelola sumber daya yang ada dan membentuk suatu pola kemitraan dengan masyarakat untuk menciptakan lapangan pekerjaan baru yang akan mempengaruhi perkembangan kegiatan ekonomi dalam daerah tersebut. Pembangunan ekonomi ini ditandai dengan meningkatnya produktivitas dan meningkatnya pendapatan per kapita penduduk sehingga terjadi perbaikan kesejahteraan. Kenyataan yang terjadi saat ini pertumbuhan ekonomi pada kabupaten/kota di Provinsi Sumatera Selatan setiap tahunnya berfluktuatif pada setiap kabupaten/kota yang juga diikuti oleh belanja modal. Hal ini dapat terjadi karena alokasi Belanja Modal suatu daerah didasarkan pada kebutuhan daerah akan sarana dan prasarana baik untuk kelancaran pelaksanaan tugas pemerintah maupun untuk fasilitas publik, sedangkan perubahan Pertumbuhan Ekonomi suatu daerah disebabkan oleh perubahan PDRB melalui peningkatan jumlah 
produksi barang dan jasa yang dibandingkan dengan jumlah penduduk suatu daerah.

Desentralisasi fiskal memberikan kewenangan yang besar kepada daerah untuk menggali potensi yang dimiliki sebagai sumber pendapatan daerah untuk membiayai pengeluaran daerah dalam rangka pelayanan publik. Berdasarkan Undang-Undang Nomor 32 Tahun 2004, salah satu sumber pendapatan daerah adalah Pendapatan Asli Daerah (PAD) yang terdiri dari hasil pajak daerah, hasil retribusi daerah, hasil pengelolaan kekayaan daerah yang dipisahkan dan lain-lain PAD yang sah. Peningkatan PAD diharapkan meningkatkan investasi belanja modal pemerintah daerah sehingga kualitas pelayanan publik semakin baik tetapi yang terjadi adalah peningkatan pendapatan asli daerah tersebut.

Setiap daerah mempunyai kemampuan keuangan yang tidak sama dalam mendanai kegiatankegiatannya, hal ini menimbulkan ketimpangan fiskal antara satu daerah dengan daerah lainnya. Oleh karena itu, untuk mengatasi ketimpangan fiskal ini, Pemerintah mengalokasikan dana yang bersumber APBN untuk mendanai desentralisasi. Salah satu dana perimbangan dari pemerintah ini adalah Dana Alokasi Umum (DAU) yang pengalokasiannya menekankan aspek pemerataan dan keadilan yang selaras dengan penyelenggaraan urusan pemerintah. Dengan adanya transfer dana dari pusat ini diharapkan pemerintah daerah bisa lebih mengalokasikan PAD yang didapatkan untuk membiayai belanja modal di daerahnya.

Berdasarkan hasil uji statistik-F variabel Pertumbuhan Ekonomi, Pendapatan Asli Daerah dan Dana Alokasi Umum berpengaruh positif signifikan terhadap anggaran belanja modal daerah pada tingkat $\alpha=$ 0,05 dengan nilai signifikan 0,004. Hal tersebut berarti bahwa secara bersama-sama Pertumbuhan Ekonomi, Pendapatan Asli Daerah dan Dana Alokasi Umum berpengaruh positif signifikan terhadap alokasi belanja modal. Hal tersebut sejalan dengan hasil penelitian yang dilakukan oleh Mayasari, dkk (2014) yang menyatakan bahwa Pertumbuhan Ekonomi, Pendapatan Asli Daerah dan Dana Alokasi Umum berpengaruh signifikan terhadap Belanja Modal.

\section{2) Pengaruh Pertumbuhan Ekonomi terhadap Pengalokasian Anggaran Belanja Modal Secara Parsial}

Pertumbuhan Ekonomi merupakan salah satu indikator keberhasilan pembangunan, atau pertumbuhan ekonomi juga dapat diartikan juga sebagai proses kenaikan kapasitas produksi suatu perekonomian yang diwujudkan dalam bentuk kenaikan pendapatan nasional yang akhirnya berpengaruh terhadap belanja modal. Tetapi dalam hal ini, faktanya bahwa pertumbuhan ekonomi tidak terlalu diperhitungkan sebagai acuan utama dalam penyusunan belanja modal. Selain itu adanya faktor yang mempengaruhi misalnya proses penyusunan anggaran setiap kabupaten/kota yang juga mempertimbangkan kondisi sosial politik di daerahnya selain memperhatikan kondisi makro ekonomi daerah.

Berdasarkan hasil uji statistik-t mengenai pengujian parsial dapat diketahui bahwa pertumbuhan ekonomi secara statistik berpengaruh negatif terhadap pengalokasian anggaran belanja modal dan terdapat pengaruh tidak signifikan secara parsial dari Pertumbuhan Ekonomi (PDRB) terhadap Pengalokasian Anggaran Belanja Modal pada Kabupaten/Kota di Provinsi Sumatera Selatan dengan nilai signifikan 0,728 $(\alpha=0,05)$. Hal ini tidak sejalan dengan penelitian yang dilakukan oleh Maslikah (2014) yang menyatakan bahwa Pertumbuhan Ekonomi tidak berpengaruh terhadap anggaran belanja modal.

\section{3) Pengaruh Pendapatan Asli Daerah terhadap Pengalokasian Anggaran Belanja Modal Secara Parsial}

Berdasarkan hasil penelitian diketahui bahwa secara umum Pendapatan Asli Daerah yang diperoleh dari 11 Kabupaten/Kota di Provinsi Sumatera Selatan didominasi dari sektor retribusi, kemudian disusul dari sektor pajak, lain-lain pendapatan asli daerah yang sah, dan kekayaan daerah yang dipisahkan.

Dari hasil penelitian menggambarkan bahwa daerah yang memiliki Pendapatan Asli Daerah tertinggi adalah kota Palembang. Pendapatan Asli Daerah terutama berasal dari pendapatan pajak daerah, lalu retribusi, lain-lain PAD serta kekayaan daerah yang dipisahkan. Sebagai Ibukota Provinsi Sumatera Selatan, Kota Palembang sangat memungkinkan untuk menggali Pendapatan Asli Daerah-nya dari sektor pendapatan pajak daerah sebab melihat kondisi Kota Palembang sebagai pusat berkumpulnya aktivitas 
perdagangan, industri, dan jasa bagi daerah-daerah sekitarnya, sehingga keadaan seperti ini menjadi peluang bagi Kota Palembang untuk menggali pajak daerahnya terutama dari pajak hotel dan restoran, hiburan, reklame, dan lain sebagainya. Akan tetapi tidak semua Pemerintah Daerah Kabupaten/Kota di Provinsi Sumatera Selatan melakukan hal yang sama untuk menggali kemampuan Pendapatan Asli Daerahnya. Hal tersebut dapat disebabkan karena kondisi geografis yang berbeda, jumlah penduduk, keadaan demografi yang beragam dan lain sebagainya.

Dari hasil analisis statistik-t terlihat bahwa Pendapatan Asli daerah sangat berpengaruh terhadap Pengalokasian Anggaran Belanja Modal dengan nilai signifikan 0,995 ( $\alpha=0,05)$. Demikian Ha yang menyatakan bahwa Pendapatan Asli Daerah mempunyai pengaruh positif terhadap Belanja Modal dapat diterima. Hal tersebut tidak sejalan dengan dengan hasil penelitian yang dilakukan oleh Widianto (2013) yang menunjukKan bahwa pendapatan asli daerah berpengaruh negatif terhadap belanja modal.

Melihat hasil penelitian di atas telah menunjukkan bahwa Pendapatan Asli Daerah (PAD) merupakan sumber pendapatan penting bagi sebuah daerah dalam memenuhi belanjanya. Daerah diharapkan dapat lebih mengoptimalkan penerimaan daerah. Pendapatan Asli Daerah secara statistik berpengaruh terhadap alokasi Belanja Modal dapat memberi sedikit acuan bahwa Pendapatan Asli Daerah sangat berperan penting dalam pembangunan daerah tersebut. Oleh karena itu daerah hendaknya lebih terpacu lagi untuk memanfaatkan sumber daya daerah untuk dapat digunakan dalam rangka kegiatan yang dapat meningkatkan pendapatan. Dengan meningkatmya Pendapatan Asli Dearah dapat memberi keleluasaan kepada daerah tersebut untuk mengalokasikan pada kegiatan atau pengeluaran yang dapat memberi dampak terhadap peningkatan pembangunan daerah terutama pembangunan infrastruktur. Peningkatan alokasi Belanja Modal dalam bentuk aset tetap seperti infrastruktur dan peralatan merupakan hal yang sangat penting untuk meningkatkan produktivitas perekonomian karena semakin tinggi Belanja Modal semakin tinggi pula produktivitas perekonomian. Dari peningkatan produktivitas perekonomian akan memberi dampak positif pada peningkatan pendapatan daerah tersebut.

\section{4) Pengaruh Dana Alokasi Umum terhadap Pengalokasian Anggaran Belanja Modal Secara Parsial}

Pada 11 Kabupaten/Kota di Provinsi Sumatera Selatan yang mendapatkan Dana Alokasi Umum tertingi adalah Kota Palembang. Tingginya Dana Alokasi Umum disebabkan oleh celah fiskal yang terjadi karena kebutuhan fiskal daerah melebihi kemampuan fiskal sehingga Pemerintah Daerah membutuhkan bantuan lain berupa Dana Alokasi Umum yang diterima. Sebenarnya Pemerintah Daerah dapat meminimalisir celah tersebut apabila Pemerintah Daerah dapat meningkatkan kemampuan fiskalnya yang salah satunya dapat dilakukan melalui Pendapatan Asli daerah yang lebih besar.

Dari hasil analisis statistik-t terlihat bahwa Dana Alokasi Umum sangat berpengaruh terhadap Pengalokasian Anggaran Belanja Modal dengan nilai signifikan 0,013 $(\alpha=0,05)$. Demikian Ha yang menyatakan bahwa Dana Alokasi Umum mempunyai pengaruh positif terhadap Belanja Modal dapat diterima. Artinya, pada saat terjadi peningkatan jumlah Dana Alokasi Umum akan berpengaruh pada peningkatan jumlah Belanja Modal. Hal tersebut sejalan dengan hasil penelitian yang dilakukan oleh Sumarmi (2008) dengan hasil penelitian menunjukkan secara parsial bahwa DAU berpengaruh negatif terhadap alokasi belanja modal.

Dana Alokasi Umum (DAU) memiliki persentase yang cukup besar dibandingkan penerimaan daerah lainnya. Jumlah ini mengindikasikan, bahwa Belanja Modal masih bergantung pada Transfer Pemerintah Pusat kepada Pemerintah Daerah. Transfer ini bermaksud untuk mengoptimalkan pelaksanaan otonomi daerah jika terjadi ketidakseimbangan antara penerimaan dan pengeluaran suatu daerah.

Dana Alokasi Umum (DAU) memungkinkan daerah menggunakan sesuai dengan prioritas dan kebutuhan daerah untuk peningkatan pelayanan kepada masyarakat dalam rangka otonomi daerah. Dari olah data dan hasil yang diperoleh mengindikasi bahwa DAU diperuntukkan untuk digunakan belanja Modal dan hanya sedikit untuk membiayai pengeluaran rutin seperti untuk belanja pegawai. 


\section{E. SIMPULAN DAN SARAN}

\section{Simpulan}

Berdasarkan hasil-hasil pengujian dan analisis yang telah dilakukan maka kesimpulan yang dapat diambil sebagai berikut:

1) Berdasarkan pengujian yang telah dilakukan bahwa Pertumbuhan Ekonomi, Pendapatan Asli Daerah dan Dana Alokasi Umum berpengaruh positif dan signifikan terhadap Belanja Modal secara Simultan.

2) Berdasarkan pengujian yang telah dilakukan bahwa Pertumbuhan Ekonomi (PDRB) bepengaruh negatif dan tidak signifikan terhadap Belanja Modal secara Parsial.

3) Berdasarkan pengujian yang telah dilakukan bahwa Pendapatan Asli Daerah berpengaruh positif dan tidak signifikan terhadap Belanja Modal secara Parsial.

4) Berdasarkan pengujian yang telah dilakukan bahwa Dana Alokasi Umum berpengaruh positif dan signifikan terhadap Belanja Modal secara Parsial.

\section{Saran}

1) Penelitian selanjutnya mungkin dapat menggunakan periode pengamatan lebih dari tiga tahun, data yang lebih lengkap, dengan data APBD dan PDRB terbaru.

2) Variabel yang digunakan dalam penelitian yang akan datang diharapkan lebih lengkap dan bervariasi, dengan menambah variabel independen lain baik ukuran-ukuran atau jenis-jenis penerimaan pemerintah daerah lainnya, maupun variabel non keuangan seperti kebijakan pemerintah, kondisi makroekonomi.

\section{REFERENSI}

Badan Pusat Statistik Kota Palembang. 2015. Produk Domestik Regional Bruto 2015.

Halim, Abdul. 2014. Akuntansi Keuangan Daerah. Edisi 4. Jakarta: Salemba Empat.

Mardiasmo. 2009. Akuntansi Sektor Publik. Edisi 4. Yogyakarta: ANDI.

Maslikah, Siti Haniatun. 2014. Pengaruh Pertunbuhan Ekonomi, Pendapatan Asli Daerah, dan Dana Alokasi Umum terhadap Pengalokasian Anggaran Belanja Modal (Study Kasus pada Kabupaten/Kota di Provinsi Jawa Tengah.Jawa Tengah: Program Studi Akuntansi Universitas Dian Nuswantoro Semarang. http://eprints.dinus.ac.id/17136/1/jurnal_15504.pdf. diakses 27 November 2017.

Mayasari, Luh Putu Rani, dkk. 2014. Pengaruh Pertumbuhan Ekonomi, Pendapatan Asli Daerah dan Dana Alokasi Umum terhadap Pengalokasian Anggaran Belanja Modal Pada Pemerintahan Kabupaten Buleleng. e-Journal S1 Ak Universitas Pendidikan Ganesha Jurusan Akuntansi Program S1. Vol. 2, No.1 Tahun 2014. http://download.portalgaruda.org. diakses 28 November 2017.

Siregar, Baldric. 2015. Akuntansi Sektor Publik. Cetakan Pertama. Edisi Pertama. Yogyakarta: Sekolah Tinggi Ilmu Manajemen YKPN.

Sujarweni, V.Wiratna. 2015. Metodologi Penelitian Bisnis dan Ekonomi. Cetakan Kesatu. Yogyakarta: Pustaka Baru Press.

Sumarmi, Saptaningsih. 2008. Pengaruh Pendapatan Asli Daerah, dana Alokasi Umum, dan Dana Alokasi Khusus terhadap Belanja Modal Daerah Kabupaten/Kota di Provinsi D.I Yogyakarta. http://upy.ac.id/ekonomi. Diakses tanggal 30 November 2017.

Pardede dan dan Rehard Manurung. 2014. Analisis Jalur (Path Analysis). Jakarta: Rineka Cipta.

Peraturan Menteri Dalam Negeri No. 52 Tahun 2015 Tentang Pedoman Penyusunan Anggaran Pendapatan dan Belanja Daerah Tahun Anggaran 2016.

Undang - Undang No.23 Tahun 2014 Tentang Pemerintahan Daerah.

Undang - Undang No. 32 Tahun 2004 Tentang Pemerintah Daerah.

Undang - Undang No. 33 Tahun 2004 Tentang Perimbangan Keuangan Antara Pemerintah Pusat dan Pemerintah Daerah.

Widianto, Andri, dkk. 2013. Pengaruh Pendapatan Asli Daerah terhadap Belanja Modal, Pertumbuhan Ekonomi dan Kemiskinan Kab/Kota di Daerah Istimewa Yogyakarta. http://www.academia.edu/. diakses tanggal 30 November 2017. 